\title{
Macro and micronutrients uptake in biomass sorghum ${ }^{1}$
}

\author{
Thomas Jefferson Cavalcante ${ }^{2}$, Gustavo Castoldi², \\ Carlos Ribeiro Rodrigues ${ }^{2}$, Matheus Martins Nogueira ${ }^{2}$, Alice Maria Albert ${ }^{2}$
}

\section{ABSTRACT}

Biomass sorghum [Sorghum bicolor (L.) Moench] is a very promising renewable source to produce energy obtained by cogeneration and fermentation processes. However, some aspects of the fertilizer management for this crop should be better understood. This study aimed to determine the accumulation progress of dry matter and macro and micronutrients in phenological stages of the biomass sorghum (Palo Alto 2562) crop, as well as to establish the accumulation order. The experiment was performed in a randomized block design, with four replicates. In order to determine the dry matter and nutrient accumulation curves, the plants were sampled in nine phenological stages (V1, V3, V5, V7, V9, V11, booting, flowering and harvest). Dry matter and N, P, K, Ca, Mg, S, Cu, $\mathrm{Fe}, \mathrm{Mn}$ and $\mathrm{Zn}$ accumulations were analyzed. The maximum dry matter accumulation was $24,853 \mathrm{~kg} \mathrm{ha}^{-1}$. $\mathrm{K}$ was the nutrient absorbed in the highest amount (447 $\left.\mathrm{kg} \mathrm{ha}^{-1}\right)$, what demonstrates the high capacity of the plant to absorb this nutrient. $\mathrm{N}$ was the second most accumulated nutrient by the plant $\left(289 \mathrm{~kg} \mathrm{ha}^{-1}\right)$ and its absorption pattern suggests that it should be supplied up to the V7 stage. It was also possible to conclude that the order of extraction and accumulation of macro and micronutrients for the biomass sorghum crops is: $\mathrm{K}>\mathrm{N}>\mathrm{Ca}>\mathrm{Mg}>\mathrm{S}>\mathrm{P}>\mathrm{Fe}>$ $\mathrm{Zn}>\mathrm{Mn}>\mathrm{Cu}$.

KEYWORDS: Sorghum bicolor (L.) Moench; fertilization; mineral nutrition; dry matter accumulation.

\section{INTRODUCTION}

In the last years, the demand for electricity in Brazil has increased, mainly due to the intensive installation of new industries in the São Paulo, Minas Gerais, Mato Grosso do Sul, Mato Grosso and Goiás states (May et al. 2013). The Alternative Energy Sources Incentive Program (Proinfa) was created to meet this scenario and the demographic progress in Brazil, aiming at developing the production

\section{RESUMO}

Marcha de absorção de macro e micronutrientes em sorgo biomassa

O sorgo biomassa [Sorghum bicolor (L.) Moench] é uma fonte renovável muito promissora para a produção de energia obtida por processos de cogeração e fermentação. Alguns aspectos do manejo da adubação para esta cultura, no entanto, devem ser melhor entendidos. Objetivou-se determinar a marcha de acúmulo de massa seca e de macro e micronutrientes em estádios fenológicos da cultura do sorgo biomassa (Palo Alto 2562), bem como estabelecer a ordem de acúmulo. $\mathrm{O}$ delineamento experimental utilizado foi o de blocos ao acaso, com quatro repetições. A fim de determinar a curva de acúmulo de massa seca e nutrientes, as plantas foram amostradas em nove estádios fenológicos (V1, V3, V5, V7, V9, V11, emborrachamento, florescimento e colheita). Analisou-se o acúmulo de massa seca e de N, P, K, Ca, Mg, S, Cu, Fe, Mn e Zn. O máximo acúmulo de massa seca foi de $24.853 \mathrm{~kg} \mathrm{ha}^{-1}$. O K foi o nutriente absorvido em maior quantidade ( $\left.447 \mathrm{~kg} \mathrm{ha}^{-1}\right)$, o que demonstra a alta capacidade da planta em absorver tal nutriente. $\mathrm{O} \mathrm{N}$ foi o segundo nutriente mais acumulado pela planta $\left(289 \mathrm{~kg} \mathrm{ha}^{-1}\right)$, e o seu padrão de absorção sugere que o seu fornecimento deve ser realizado até o estádio V7. Conclui-se, ainda, que a ordem de extração e acúmulo de macro e micronutrientes para a cultura do sorgo biomassa é a seguinte: $\mathrm{K}>\mathrm{N}>\mathrm{Ca}>\mathrm{Mg}>\mathrm{S}>\mathrm{P}>\mathrm{Fe}>\mathrm{Zn}>\mathrm{Mn}>\mathrm{Cu}$.

PALAVRAS-CHAVES: Sorghum bicolor (L.) Moench; adubação; nutrição mineral; acúmulo de massa seca.

of plant biomass to be used as raw material for electricity generation. In this context, biomass sorghum [Sorghum bicolor (L.) Moench] is a crop that has been highlighted for this purpose (Castro et al. 2015).

Biomass sorghum is a $\mathrm{C} 4$ plant of tropical origin and with a high efficiency in dry and marginal environments (Amaducci et al. 2016). Unlike alternative crops such as energy cane and elephant grass, its propagation is performed by seeds, what

1. Received: Mar. 06, 2018. Accepted: Jun. 20, 2018. Published: Nov. 08, 2018. DOI: 10.1590/1983-40632018v4851874.

2. Instituto Federal de Educação, Ciência e Tecnologia Goiano, Laboratório de Química Agrícola, Rio Verde, GO, Brasil.

E-mail/ORCID: tjc_net@hotmail.com/0000-0003-0332-2390, gustavo.castoldi@ifgoiano.edu.br/0000-0002-2206-2830, carlos.rodrigues@ifgoiano.edu.br/0000-0001-7533-1179, matheusmartinsnog@gmail.com/0000-0002-3774-2193, aliceberft@hotmail.com/0000-0002-3453-9333. 
is an advantage, since it allows the use of seeders in their implantation, guaranteeing agility and homogeneity in the field (Silva et al. 2017). Besides, its cultivation is done almost exclusively for the supply of raw material to generate energy by direct combustion in power plants and to produce second generation bioethanol (Campi et al. 2016, Serra et al. 2017).

The biomass sorghum capacity to produce dry matter is high, reaching $40 \mathrm{tha}^{-1}$ for the variety CMSXS 7012, grown in three regions of the Minas Gerais state, Brazil, and fertilized with $450 \mathrm{~kg} \mathrm{ha}^{-1}$ of the formulation $08-28-16$ and with $200 \mathrm{~kg} \mathrm{ha}^{-1}$ of urea applied as topdressing (Castro et al. 2015). However, some aspects of its management should be better understood to increase yield and reduce costs. One of these aspects is related to fertilization management, which is often based on the guidelines made for corn crops. For example, it is known that, for each ton of dry matter produced, the variety CMSXS 652 extracts $7.63 \mathrm{~kg}, 1.09 \mathrm{~kg}, 9.22 \mathrm{~kg}$, $3.18 \mathrm{~kg}, 2.41 \mathrm{~kg}$ and $0.64 \mathrm{~kg}$ of $\mathrm{N}, \mathrm{P}, \mathrm{K}, \mathrm{Ca}, \mathrm{Mg}$ and $\mathrm{S}$, respectively (Santos et al. 2015). A recent trial with modern biomass sorghum materials showed that $\mathrm{N}$ fertilization above $60 \mathrm{~kg} \mathrm{ha}^{-1}$ do not affect the dry matter gain, but it affects the amount of nutrient exported, suggesting that the crop can absorb more $\mathrm{N}$ than its real need (Ameen et al. 2017).

It is extremely important to know the nutritional needs of plants according to their phenological stages to be able to build fertilization management plans, especially for modern genotypes with a high productive potential (Santos et al. 2014). The main recommendations for sorghum fertilization in the country are outdated and apply to grain or forage sorghum cultivars that have a lower biomass generation potential than the biomass sorghum (Ribeiro et al. 1999, Souza \& Lobato 2004). Thus, there are no recommendations and no knowledge to identify the period of greatest accumulation, potential and order of extraction and accumulation of nutrients for biomass sorghum.

Studies on uptake are important to increase the efficiency of crop fertilization, since the real demand for nutrients by the crop can be understood. In this context, this study aimed to determine the progress of dry matter and macro and micronutrients accumulation in phenological stages of biomass sorghum, as well as to establish the accumulation order.

\section{MATERIAL AND METHODS}

A descriptive study was carried out on the growth and accumulation of macro and micronutrients in biomass sorghum under field conditions, at the experimental station of the Nexsteppe Sementes do Brasil, located in Rio Verde, Goiás state, Brazil

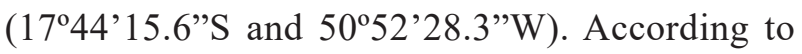
the Köppen-Geiger classification, the climate of the region is tropical, with a dry season during the winter (Aw), average annual rainfall of 1,400-1,600 mm and average temperature of $23-24^{\circ} \mathrm{C}$ (Cardoso et al. 2015).

The experiment was carried out from 15 November 2016 to 19 February 2017. The soil of the experimental area was characterized as a typical Dystrophic Red Latosol, presenting, in the $0.0-0.2 \mathrm{~m}$ layer, $460 \mathrm{~g} \mathrm{~kg}^{-1}$ of clay, $50 \mathrm{~g} \mathrm{~kg}^{-1}$ of silt and $490 \mathrm{~g} \mathrm{~kg}^{-1}$ of sand. The soil was sampled and analyzed before the experiment implantation. The chemical characteristics were determined according to Embrapa (2009) and showed the following results: $\mathrm{pH}$ $\left(\mathrm{CaCl}_{2}\right)=5.6$; O.M. $=40.6 \mathrm{~g} \mathrm{dm}^{-3}$, determined based on acid dichromate oxidation; $\mathrm{P}=16.03 \mathrm{mg} \mathrm{dm}^{-3}$ and $\mathrm{K}=0.13 \mathrm{cmol}_{\mathrm{c}} \mathrm{dm}^{-3}$, extracted with Mehlich-1; $\mathrm{Ca}=2.64 \mathrm{cmol}_{\mathrm{c}} \mathrm{dm}^{-3}$ and $\mathrm{Mg}=1.16 \mathrm{cmol}_{\mathrm{c}} \mathrm{dm}^{-3}$, extracted with $1.0 \mathrm{~mol} \mathrm{~L}^{-1}$ of $\mathrm{KCl}$ solution; $\mathrm{H}+\mathrm{Al}=$ $3.08 \mathrm{cmol}_{\mathrm{c}} \mathrm{dm}^{-3}$ and $\mathrm{Al}=0.01 \mathrm{cmol} \mathrm{dm}_{\mathrm{c}}^{-3}$, extracted in calcium acetate solution; $\mathrm{SB}=3.93 \mathrm{cmol}_{\mathrm{c}} \mathrm{dm}^{-3} ; \mathrm{CEC}=$ $7.01 \mathrm{cmol} \mathrm{dm}^{-3}$; and $\mathrm{V}=56 \%$. The micronutrients $\mathrm{Fe}$ $\left(15 \mathrm{mg} \mathrm{dm}^{-3}\right), \mathrm{Mn}\left(33.55 \mathrm{mg} \mathrm{dm}^{-3}\right), \mathrm{Cu}\left(4.9 \mathrm{mg} \mathrm{dm}^{-3}\right)$ and $\mathrm{Zn}\left(5.9 \mathrm{mg} \mathrm{dm}^{-3}\right)$ were extracted with Mehlich-3 solution.

Palo Alto 2562 biomass sorghum from the Nexsteppe Sementes do Brasil was used. It presents a late cycle, with a flowering period of 80 to 90 days, being recommended for sowing in November and December. It is a hybrid with a low tiller emission potential and presents a short-day photosensitivity (Nexsteppe 2015).

To determine the dry matter and nutrient accumulation curve, the plants were sampled into nine growth stages: V1, V3, V5, V7, V9, V11, booting, flowering and harvest. Sampling was performed at random with zigzag walking in the area. A composite sample was collected in each of the four replicates. The collections were performed at 5, 11, 17, 25, 33, $45,72,81$ and 95 days after emergence, when more than $50 \%$ of the plants were in the stage in question. As there is no specific phenological scale for biomass sorghum, some concepts for the identification of the 
phenological stages were based on Kochenower et al. (2016) and according to what is conventionally used for field management purposes.

Sowing was performed with a no-tillage mechanical fertilizer equipped with a vacuum system with six rows spaced $0.50 \mathrm{~m}$ apart and searching a population of 240,000 plants $\mathrm{ha}^{-1}$, which was precisely adjusted for 120,000 plants ha ${ }^{-1}$ at thinning ( 5 days after sowing at $\mathrm{V} 1$ - first fully expanded true leaf). Each plot was composed of 6 lines of $30 \mathrm{~m}$ in length each.

The fertilization was performed based on recommendation by the Nexsteppe company to ensure that no nutritional deficiencies would occur and that the hybrid could express its maximum production potential (adapted from Nexsteppe 2015). In the sowing furrow, $38.4 \mathrm{~kg} \mathrm{ha}^{-1}$ of N, $134.4 \mathrm{~kg} \mathrm{ha}^{-1}$ of P and $76.8 \mathrm{~kg} \mathrm{ha}^{-1}$ of $\mathrm{K}$ were added. For topdressing, the application of $160 \mathrm{~kg} \mathrm{ha}^{-1}$ of $\mathrm{N}$ and $160 \mathrm{~kg} \mathrm{ha}^{-1}$ of $\mathrm{K}$ were divided into two phases, one at the V5 stage and the other at V9. At $\mathrm{V} 9$, magnesium sulphate $\left(1 \mathrm{~kg} \mathrm{ha}^{-1}\right)$ was also applied to prevent a temporary deficiency of $\mathrm{Mg}$ - typical of this hybrid, as well as $1 \mathrm{~L} \mathrm{ha}^{-1}$ of S and a micronutrient based product $(\mathrm{S}=6.90 \%$; $\mathrm{B}=0.20 \% ; \mathrm{Cu}=0.50 \%$; $\mathrm{Mn}=8 \% ; \mathrm{Mo}=0.05 \% ; \mathrm{Zn}=3 \%)$. Applications of the insecticides Thiamethoxam and Alfa-Cipermethrin were performed at 11 and 23 days after emergence (DAE), for the chemical control of the Spodoptera frugiperda caterpillar. There was no problem with weeds or disease incidence.

The samples were washed in distilled water and separated into stem, leaves and panicle. At V1 and V3, the plant was not separated into parts and a total of 45 plants per plot was also sampled to have enough plant material for the analyzes. Panicles were separated only at flowering and harvest. The plant material was placed in paper bags and submitted to a forced air circulation oven at $65^{\circ} \mathrm{C}$, until constant mass. The samples were weighed (to determine the dry matter accumulation), ground in a Willey-type mill and analyzed for N, P, K, Ca, Mg, S, Cu, Fe, Mn and $\mathrm{Zn}$ (Embrapa 2009).

At harvest, to characterize the final product, the plant height (measured from the soil surface to the panicle), stem diameter (measured in the third node counted from the bottom up), calorific value production and fresh mass production were also measured. The total shoot dry matter of the plants was obtained with the sum of the dry matter values of leaf, stem and panicles. The accumulation of nutrients in each part of the plant was calculated by multiplying the nutrient content by the dry matter of each part and the values were obtained in $\mathrm{kg} \mathrm{ha}^{-1}$.

To characterize the sampling times, images of the plants were obtained in each of the phenological stages, in their respective days of evaluation. Therefore, plants were selected, measured and photographed and the images were processed by the Corel Draw X7 software.

Since the data are quantitative and there is a correlation between DAE (x) and dry matter production or nutrients accumulation (y), they were analyzed by a non-linear regression model, a Gaussian function with three parameters, following the procedure described by Borges et al. (2016), from the equation $\mathrm{Y}=\mathrm{a} /\left\{1+\exp -\left[\left(\mathrm{X}-\mathrm{X}_{0}\right] / \mathrm{b}\right)\right\}$, where $a$ is the maximum curvature point, $b$ the setting parameter and $X_{0}$ the inflection point.

The inflection point corresponds to the moment in which the maximum rates of dry matter and nutrients accumulation occurred in the biomass sorghum plants. The minimum $\left(\mathrm{PC}_{\min }\right)$ and maximum $\left(\mathrm{PC}_{\max }\right)$ points of curvature were calculated according to the method described by Venegas et al. (1998), using the parameters of the nonlinear equations $\mathrm{PC}_{\text {min }}=\mathrm{X}_{0}-2 \mathrm{~b}$ and $\mathrm{PC}_{\text {max }}=\mathrm{X}_{0}+2 \mathrm{~b}$, where $P C_{\text {min }}$ indicates the moment when there were significant gains in the accumulation of dry matter and nutrients and $P C_{\max }$ the moment when the accumulation of the elements begins to stabilize.

\section{RESULTS AND DISCUSSION}

Samples were collected at 5, 11, 17, 25, 33, $45,72,81$ and $95 \mathrm{DAE}$ and corresponded to the phenological stages V1, V3, V5, V7, V9, V11 and harvest, respectively (Figure 1). In terms of height, it was observed that the plant presented a relatively slow growth up to V11, from which the growth rate increased.

As characterization of the final production, at the harvest time, Palo Alto 2562 reached an average height of $4.33 \mathrm{~m}$, average stem diameter of $2.1 \mathrm{~cm}$ and fresh mass production of $64,925 \mathrm{~kg} \mathrm{ha}^{-1}$, with a calorific value of $3,620 \mathrm{kcal} \mathrm{kg}^{-1}$. These agronomic characteristics are close to the reports for the sorghum CMSXS 7015 cultivar, which, in a clayey soil test, showed a height ranging from $5.24 \mathrm{~m}$ and $4.83 \mathrm{~m}$ and an average stem diameter of $1.9 \mathrm{~cm}$ (May et al. 2016). 
The accumulation of total dry matter was slow in the initial stages, precisely up to 35 DAE (near the V9 stage). From this moment, the accumulation of dry matter increased significantly up to 68 DAE (Figure 2), close to the booting stage, when the rates returned to stabilize at a lower level. In this 39-day interval, the crop went from $2,307 \mathrm{~kg} \mathrm{ha}^{-1}$ to $22,531 \mathrm{~kg} \mathrm{ha}^{-1}$ of dry matter, representing an accumulation of $20,224 \mathrm{~kg} \mathrm{ha}^{-1}$ (Figure 2). This interval coincides with the transition from the vegetative to the reproductive phase, and the increase of dry matter, in this period, is due to the increase of the leaf area and photoassimilated reserves in the stems, which will be translocated during the reproductive phase, just like results found for wheat (Streckll \& Rosalll 2009).

According to the adjusted model (Figure 2), the maximum accumulation of total dry matter was $24.43 \mathrm{tha}^{-1}$, at $95 \mathrm{DAE}$. The dry matter accumulated

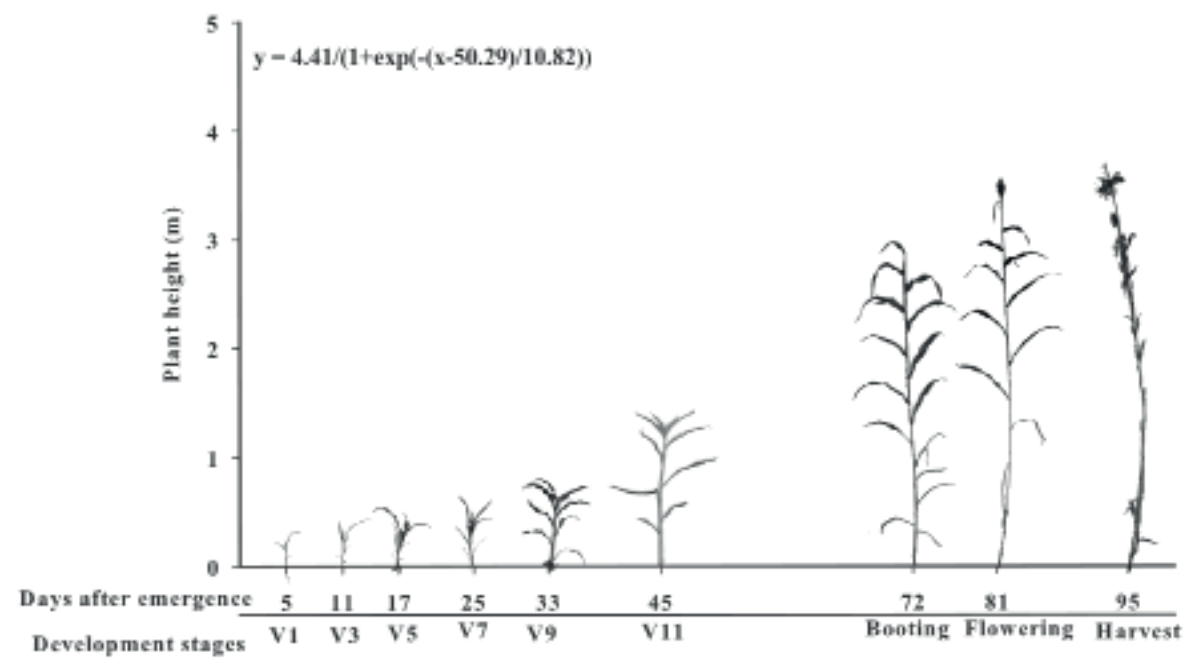

Figure 1. Phenological stages of biomass sorghum in which the nutrient uptake and corresponding height were collected. * Only the main stem is shown in the figure (tillering starts from V5). V1: first true fully expanded leaf (emerged after the cotyledon leaf); V3, V5, V7, V9 and V11: 3, 5, 7, 9 and 11 fully expanded true leaves; booting: emergence of the flag leaf; flowering: panicle appearance; harvest: performed as soon as the stem humidity is below $55 \%$ (in the field: $>75 \%$ of dry leaves). Source: Cavalcante et al. (2018).

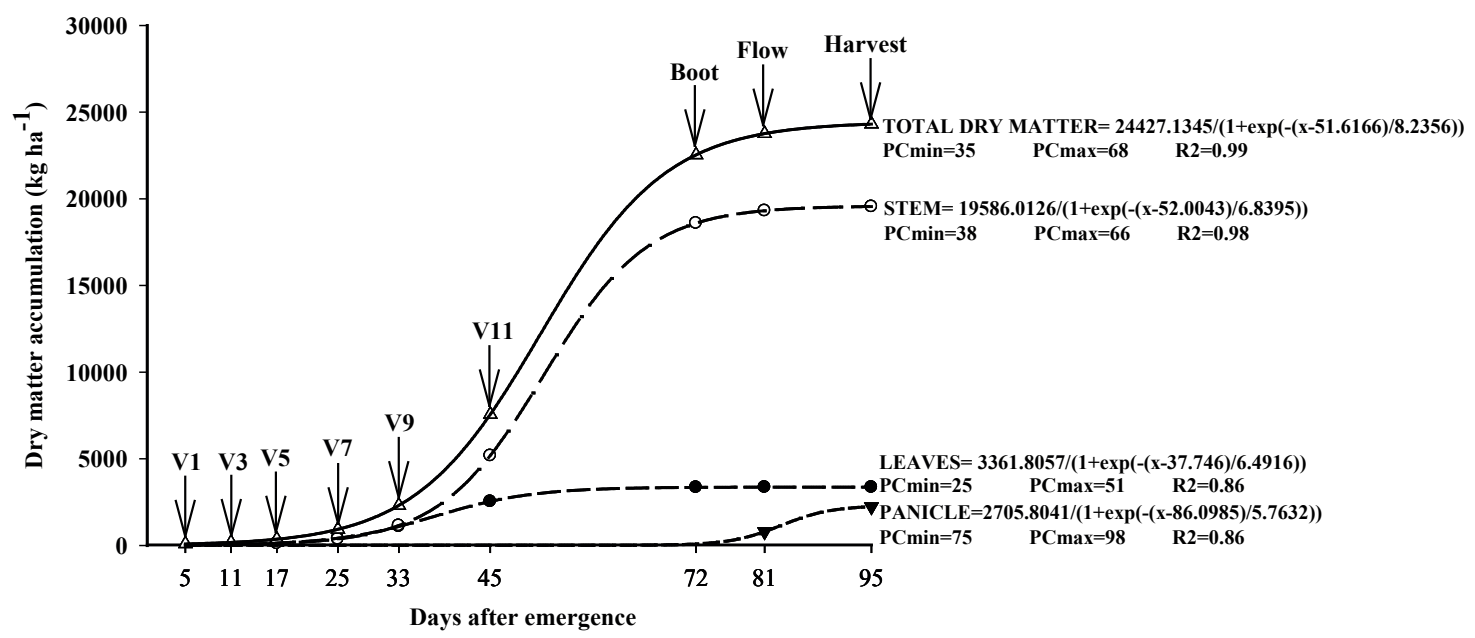

Figure 2. Shoot dry matter accumulation of biomass sorghum, as a function of days after emergence. For models adjusted according to days after emergence, in relation to the total dry matter, stem, leaf and panicle, the minimum point of curvature (PCmin) indicates the beginning of expressive gains in the dry accumulation. The maximum point of curvature (PCmax) indicates the moment when the accumulation of the elements begins to stabilize. 
by the biomass sorghum is one of the characteristics that makes this crop a good raw material option for cogeneration of energy. Values above $20 \mathrm{t} \mathrm{ha}^{-1}$ of dry matter (23.1-26.3 $\left.\mathrm{t} \mathrm{ha}^{1}\right)$ were observed in a two-year experiment, with three hybrids of biomass sorghum (harvest between 127 and 140 DAE) cultivated on a clayey soil, in Italy (Pannacci \& Bartolini 2016).

The greatest contribution to the dry matter production was determined by the accumulation in the stems (Figure 2), with $77.8 \%$ of all the dry matter accumulation, remaining $13.4 \%$ for the leaves and $8.8 \%$ for the panicles (Figure 2). As the biomass sorghum is a crop that will be used to feed furnaces in power plants and to produce second generation ethanol, the low accumulation of dry matter in the panicle, and consequent accumulation of more fibrous material in the stems, is highly desirable. Santos et al. (2014) also found a close relationship ( $76.34 \%, 17.69 \%$ and $5.59 \%$ for stems, leaves and panicles, respectively), in a study with the CMSXS 7020 hybrid cultivated on a typical Dystroferric Red Latosol, with the application of $240 \mathrm{~kg} \mathrm{ha}^{-1}$ and $180 \mathrm{~kg} \mathrm{ha}^{-1}$ of $\mathrm{N}$ and $\mathrm{K}$, respectively.

The total accumulation of $\mathrm{N}$ in the early stages was slow, particularly up to $26 \mathrm{DAE}(\approx \mathrm{V} 7$ stage $)$ (Figure 3a). Thus, it is suggested that the topdressing nitrogen fertilization for biomass sorghum cultivation should be done before the V7 stage, because the highest accumulation rates of $\mathrm{N}$ were between 26 and 57 DAE, when the plant absorbed and accumulated $216.9 \mathrm{~kg} \mathrm{ha}^{-1}$ of N. From this point, the $\mathrm{N}$ accumulation stabilized, reaching the maximum accumulation of $288.9 \mathrm{~kg} \mathrm{ha}^{-1}$ at harvest (Figure 3a). The high accumulation of $\mathrm{N}$ in the vegetative phase of biomass sorghum, just as it occurs for grain sorghum (Borges et al. 2006), is probably related to functions that the nutrient exerts on the biochemical processes of the plant, as a constituent of proteins, enzymes, coenzymes, nucleic acids, phytochromes and chlorophyll (Fornasieri Filho 2007).

The amount of $\mathrm{N}$ absorbed by the crop (289 $\mathrm{kg} \mathrm{ha}^{-1}$ ) was higher than the amount supplied through fertilization, planting and topdressing, which reached $198 \mathrm{~kg} \mathrm{ha}^{-1}$ of $\mathrm{N}$ (as urea). This difference may have been supplied by the soil, via inorganic $\mathrm{N}$ uptake from the mineralization of the organic matter or even via biological $\mathrm{N}$ fixation, since sorghum is a plant capable of promoting symbiotic associations with $\mathrm{N}$-fixing microorganisms, as observed by Bergamaschi et al. (2007), when they exposed 14 sorghum cultivars to $\mathrm{N}$-fixing microorganisms and found an accumulation of 3.78-229.72 $\mu \mathrm{g} \mathrm{N} .(\mathrm{mg}$ protein $)^{-1}$.day ${ }^{-1}$.

The high uptake and export of $\mathrm{N}$ by the biomass sorghum has been reported in other studies. In an experiment conducted using a typical Dystrophic Red Latosol, the CMSXS 652 variety extracted $242 \mathrm{~kg} \mathrm{ha}^{-1}$ of $\mathrm{N}$ to produce $33.95 \mathrm{Mg} \mathrm{ha}^{-1}$ of dry matter, with fertilization of $80 \mathrm{~kg} \mathrm{ha}^{-1}$ of $\mathrm{N}$ (Santos et al. 2015).

The $\mathrm{P}$ accumulation rate reduced up to the $\mathrm{V} 7$ stage (28 DAE) (Figure 3b). This period of slow $\mathrm{P}$ accumulation in the shoot may be related to the root growth phase, which is very important in the plant support and reached an average height of $4.52 \mathrm{~m}$ (Figure 1). The initial establishment of Poaceae plants is characterized by a fast root growth, a process that is very dependent on $\mathrm{P}$ (Guedes et al. 2011).

The highest accumulation rate of $\mathrm{P}$ was between 28 and 59 DAE, when the plant accumulated $29.69 \mathrm{~kg} \mathrm{ha}^{-1}$ (Figure 3b), and, in that period, increased by $2.54 \mathrm{~m}$. The maximum $\mathrm{P}$ accumulation at harvest was $37.8 \mathrm{~kg} \mathrm{ha}^{-1}$ (Figure 3b). Phosphorus was the macronutrient less absorbed by the biomass sorghum, and the rates commonly recommended seem to meet such demand. However, it is essential that this demand be reached, since the adequate supply of $\mathrm{P}$ increases the lignin production in the Poaceae stem (Shan et al. 2018), a characteristic very desirable for the cultivation of biomass sorghum.

The close relationship between the absorption of $\mathrm{P}$ and $\mathrm{N}$ can be observed in the Figures $3 \mathrm{a}$ and $3 \mathrm{~b}$. For the total accumulation of $\mathrm{N}$ and $\mathrm{P}$, the minimum points of curvature were 26 and 28 and the maximum points of curvature were 57 and 59, respectively. The absorption of $\mathrm{K}$ showed a fast initial accumulation, when compared to $\mathrm{N}$ and $\mathrm{P}$, mainly because the higher absorption rates were concentrated between V7 (25 DAE) and V11 (48 DAE) and did not extend to the booting stage (Figure $3 \mathrm{c}$ ). In this context, the topdressing fertilization with $\mathrm{K}$ for the biomass sorghum must be performed before V7. A higher demand for $\mathrm{K}$ in the initial stage of the sorghum development makes it a "starter element", mainly for Poaceae (Coelho et al. 2002).

Besides the high absorption rates, $\mathrm{K}$ is the most accumulated nutrient by the crop, reaching $447 \mathrm{~kg} \mathrm{ha}^{-1}$ at harvest. High values of K accumulation in the shoot biomass were also observed by Santos et al. (2015), who verified a $298 \mathrm{~kg} \mathrm{ha}^{-1}$ extraction 
of $\mathrm{K}$ in a dry matter production of $33.95 \mathrm{Mg} \mathrm{ha}^{-1}$, with fertilization of $180 \mathrm{~kg} \mathrm{ha}^{-1}$ of $\mathrm{K}$, in a CMSXS 652 variety.

The amount of $\mathrm{K}$ accumulated in the biomass sorghum shoot (447 $\left.\mathrm{kg} \mathrm{ha}^{-1}\right)$ was higher than the amount provided by fertilization $\left(236.8 \mathrm{~kg} \mathrm{ha}^{-1}\right)$. Part of this excess could have been supplied by the K available in the soil, which, according to the analysis $\left(0.13 \mathrm{cmol}_{\mathrm{c}} \mathrm{dm}^{-3}\right)$, could make up to $101.4 \mathrm{~kg} \mathrm{ha}^{-1}$ of $\mathrm{K}$ (0.0-0.2 $\mathrm{m}$ layer). Based on this difference, it
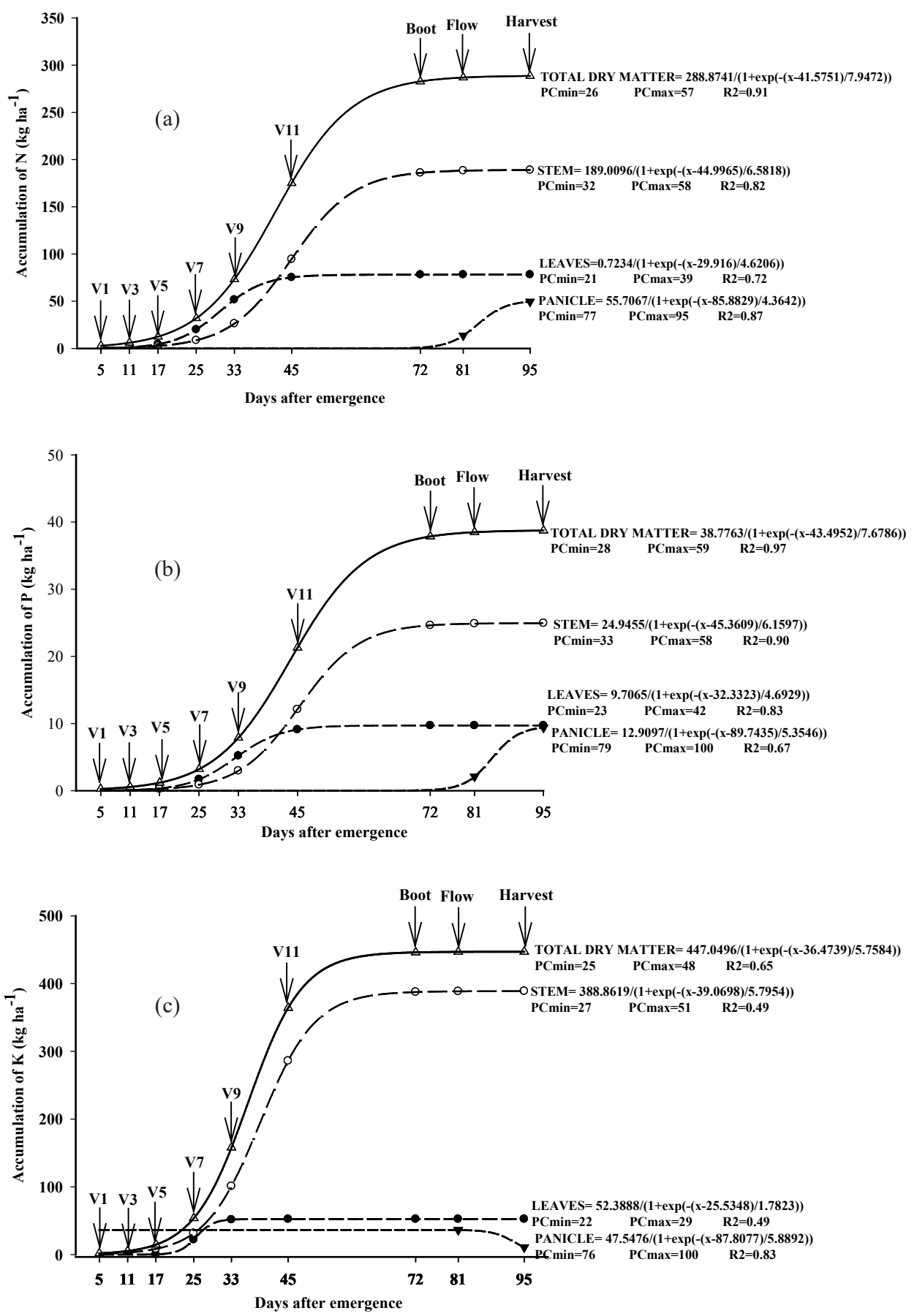

Figure 3. Accumulation of nitrogen (a), phosphorus (b) and potassium (c) in the biomass sorghum shoot, as a function of days after emergence. The models were adjusted according to days after emergence, in relation to the total dry matter, stem, leaf and panicle. The minimum point of curvature (PCmin) indicates the beginning of expressive gains in the accumulation of $\mathrm{N}$, $\mathrm{P}$ and $\mathrm{K}$. The maximum point of curvature (PCmax) indicates the moment when the accumulation of the elements begins to stabilize. 
can be hypothesized that the other part of the excess would come from the non-exchangeable fraction of $\mathrm{K}$. Biomass sorghum is considered a species with a high ability of $\mathrm{K}$ cycling, due to the high $\mathrm{K}$ uptake.

Calcium was the third most accumulated element, reaching $99.3 \mathrm{~kg} \mathrm{ha}^{-1}$ at harvest (Figure $4 \mathrm{a}$ ).
Its accumulation occurred slowly up to $32 \mathrm{DAE}$, close to the V9 stage (Figure 4a). Calcium absorption is highly dependent on respiratory flow, as well as its absorption can be reduced by the absorption of $\mathrm{K}$ (Carpaneto \& Gradogna 2018). So, it is possible to assume that the amount of $\mathrm{Ca}$ uptake by the
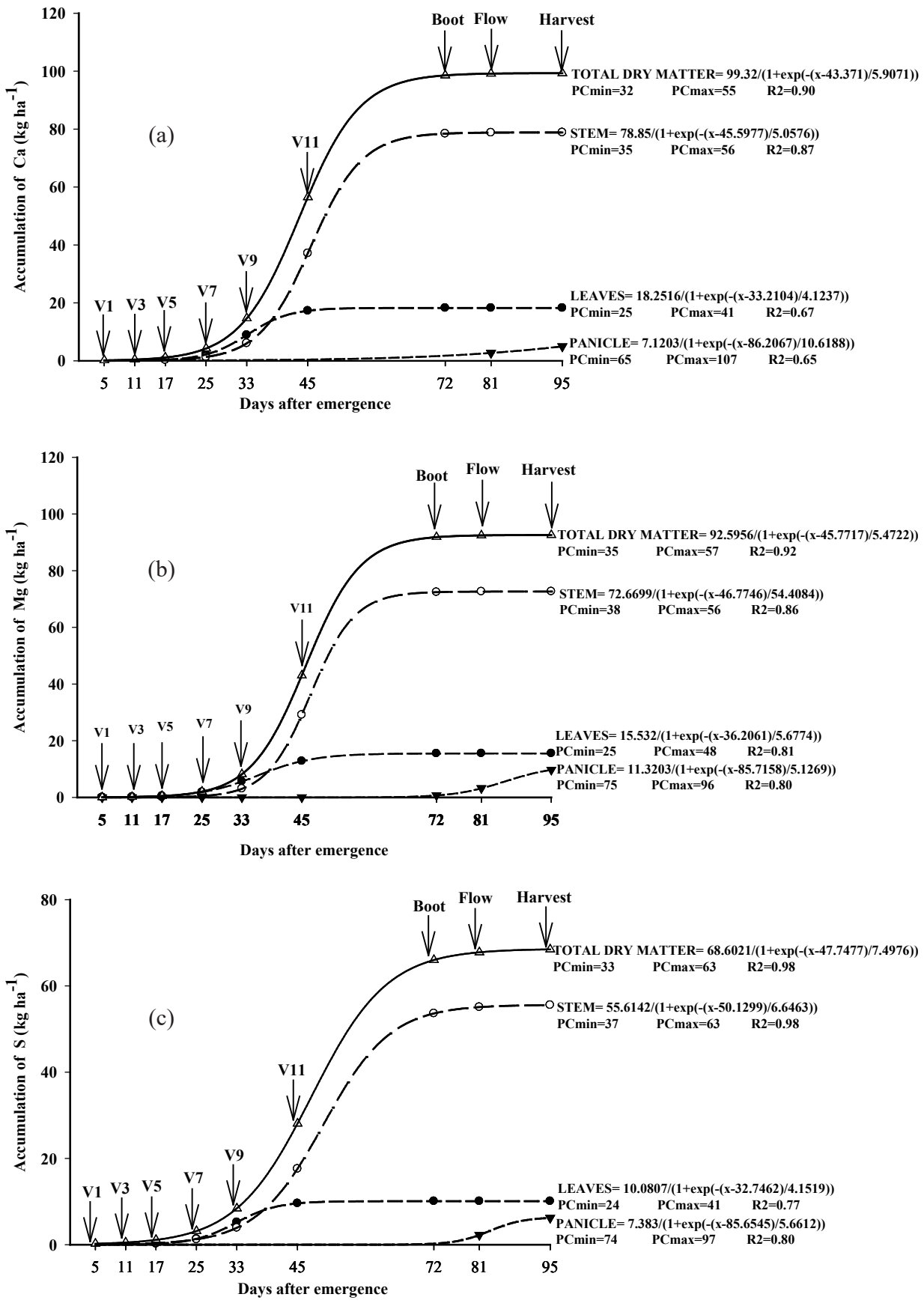

Figure 4. Accumulation of calcium (a), magnesium (b) and sulfur (c) in the biomass sorghum shoot, as a function of days after emergence. The models were adjusted according to days after emergence, in relation to the total dry matter, stem, leaf and panicle. The minimum point of curvature ( $\mathrm{PCmin}$ ) indicates the beginning of significant gains in the accumulation of $\mathrm{Ca}$, $\mathrm{Mg}$ and $\mathrm{S}$. The maximum point of curvature (PCmax) indicates the moment when the accumulation of the elements begins to stabilize. 
biomass sorghum could be even higher, if the amount of $\mathrm{K}$ uptake was lower. The highest rates of $\mathrm{Ca}$ accumulation were between 32 and 55 DAE (Figure 4a), a period that largely coincides with the highest accumulation of dry matter (Figure 2).

The total accumulation of $\mathrm{Mg}$ was slow up to 35 DAE (close to the V9 stage) (Figure 4b). The highest absorption rates of $\mathrm{Mg}$ were at 35-57 DAE, when the absorption stabilized, culminating in the maximum accumulation of $92.6 \mathrm{~kg} \mathrm{ha}^{-1}$ at harvest (Figure $4 \mathrm{~b}$ ). In this 22-day interval, the crop went from $11.6 \mathrm{~kg} \mathrm{ha}^{-1}$ to $82.1 \mathrm{~kg} \mathrm{ha}^{-1}$ of $\mathrm{Mg}$, representing an accumulation of $70.7 \mathrm{~kg} \mathrm{ha}^{-1}$ (Figure $4 \mathrm{~b}$ ). The higher $\mathrm{Mg}$ accumulation rate in this period may be related to its important role in the plant metabolism, its presence in chlorophyll molecules and, mainly, its participation in processes of enzymatic activation, transport of elements and as a P carrier (Epstein \& Bloom 2006).

The total accumulation of $\mathrm{S}$ was slow up to the V9 stage (Figure 4c), so that the highest accumulation rates were between 33 and 63 DAE. In this 30-day interval, the crop went from $8.4 \mathrm{~kg} \mathrm{ha}^{-1}$ to $60.7 \mathrm{~kg} \mathrm{ha}^{-1}$ of $\mathrm{S}$, representing an accumulation of $52.3 \mathrm{~kg} \mathrm{ha}^{-1}$ (Figure $4 \mathrm{~b}$ ). This period also coincides with the period of greatest accumulation of dry matter by the crop (Figure 2). Knowing that $\mathrm{S}$ is an essential macronutrient for being incorporated into amino acids or sulfur-containing metabolites, it plays a crucial role for plant growth and adaptation to stress (Forzani et al. 2018), what might explain the higher demand by $\mathrm{S}$ in the period of higher dry matter accumulation. Sulfur and $\mathrm{Ca}$ are considered to be immobile nutrients in the plant, with a very low rate of redistribution after reaching some organs of the plants; the leaves, for instance (Taiz et al. 2017). For both elements, the leaves presented the maximum point of curvature at 41 DAE (Figures $4 \mathrm{a}$ and $4 \mathrm{c}$ ).

In general, the accumulation of micronutrients in the biomass sorghum shoot was slow up to the V9 stage (30-32 DAE) (Figure 5). From that point on, the absorption rates increased significantly. However, for $\mathrm{Fe}$ and $\mathrm{Mn}$, this most intense absorption period was very slow, starting at $32 \mathrm{DAE}$ and stabilizing at 38 and $37 \mathrm{DAE}$, respectively (Figure 5). Therefore, almost the total absorption of $\mathrm{Fe}$ and $\mathrm{Mn}$ was between 5 and 6 days. Fe was the most absorbed micronutrient by the crop and its accumulation reached 2,027 $\mathrm{g} \mathrm{ha}^{-1}$. This high $\mathrm{Fe}$ accumulation for biomass sorghum may indicate that $\mathrm{Fe}$ is the most limiting micronutrient, as observed for grain sorghum, when the omission of Fe greatly affected the dry matter accumulation (Santi et al. 2005). On the other hand, however, high concentrations of Fe may limit the accumulation of Mn in sorghum, as also observed by Santi et al. (2005).

Differently from what was observed for Fe and $\mathrm{Mn}$, the most intense absorption period was longer for $\mathrm{Cu}$ and $\mathrm{Zn}$, starting at $30 \mathrm{DAE}$ and extending, respectively, to 55 and 56 DAE, between V11 and booting. The maximum accumulation of $\mathrm{Zn}$ was $1,015 \mathrm{~g} \mathrm{ha}^{-1}$, being the second most accumulated micronutrient, what may be related to the high sensitivity of sorghum to $\mathrm{Zn}$ deficiency (Santos et al. 2009). Cu was the least absorbed micronutrient,

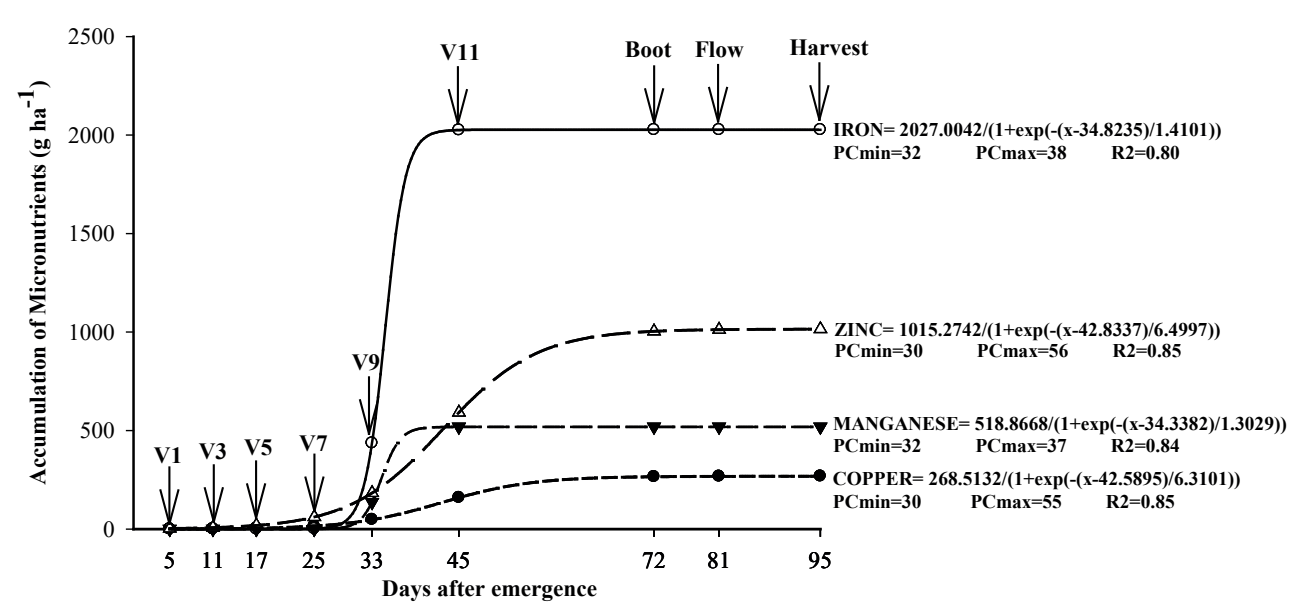

Figure 5. Micronutrient accumulation in the biomass sorghum shoot, as a function of days after emergence. The minimum point of curvature (PCmin) indicates the beginning of significant gains in the accumulation of iron, zinc, manganese and copper. The maximum point of curvature (PCmax) indicates the moment when the accumulation of the elements begins to stabilize. 
with $268 \mathrm{~g} \mathrm{ha}^{-1}$ (Figure 5). The reduced $\mathrm{Cu}$ absorption may be related to the antagonistic bivalent cation absorption relationships, as observed by Santos et al. (2009) for grain sorghum.

The total demand for macro and micronutrients was in the following order: $\mathrm{K}>\mathrm{N}>\mathrm{Ca}>\mathrm{Mg}>\mathrm{S}>\mathrm{P}>$ $\mathrm{Fe}>\mathrm{Zn}>\mathrm{Mn}>\mathrm{Cu}$. Among the component fractions of the plant, the greatest nutrients accumulation was in the stems, followed by the leaves and panicles, due to the greater dry matter accumulation.

\section{CONCLUSIONS}

1. The maximum shoot dry matter accumulation of the biomass sorghum (24.43 $\left.\mathrm{Mg} \mathrm{ha}^{-1}\right)$ takes place at harvest, at 95 days after emergence;

2. The order of macro and micronutrient demand for the biomass sorghum crop is the following one: $\mathrm{K}>\mathrm{N}>\mathrm{Ca}>\mathrm{Mg}>\mathrm{S}>\mathrm{P}>\mathrm{Fe}>\mathrm{Zn}>\mathrm{Mn}>\mathrm{Cu}$;

3. The absorption pattern of $\mathrm{N}$ and $\mathrm{K}$ suggests that topdressing fertilization (at least part of it) should be performed before the V7 stage. The P supply can be performed at sowing, and a possible deficiency of micronutrients can be corrected by foliar application and must be done before the V9 stage.

\section{REFERENCES}

ALMEIDA, B. E. et al. Acúmulo e remobilização de nitrogênio em variedades de milho. Revista Caatinga, v. 19, n. 3, p. 278-286, 2006.

AMADUCCI, S. et al. Effect of irrigation and nitrogen fertilization on the production of biogas from maize and sorghum in a water limited environment. European Journal of Agronomy, v. 76, n. 1, p. 54-65, 2016.

AMEEN, A. et al. Biomass yield and nutrient uptake of energy sorghum in response to nitrogen fertilizer rate on marginal land in a semi-arid region. BioEnergy Research, v. 10, n. 2, p. 363-376, 2017.

BERGAMASCHI, C. et al. Ocorrência de bactérias diazotróficas associadas a cultivares de sorgo forrageiro. Ciência Rural, v. 37, n. 3, p. 727-733, 2007.

BORGES, I. D. et al. Acúmulo de macronutrientes na cultura do sorgo granífero na safrinha. Revista Brasileira de Milho e Sorgo, v. 15, n. 2, p. 294-304, 2016.

CAMPI, P. et al. Energy of biomass sorghum irrigated with reclaimed wastewaters. European Journal of Agronomy, v. 76, n. 1, p. 176-185, 2016.
CARDOSO, M. R. D. et al. Classificação climática de Köppen-Geiger para o estado de Goiás e o Distrito Federal. Acta Geográfica, v. 8, n. 16, p. 40-55, 2015.

CARPANETO, A.; GRADOGNA, A. Modulation of calcium and potassium permeation in plant TPC channels. Biophysical Chemistry, v. 236, n. 1, p. 1-7, 2018.

CASTRO, F. M. R. et al. Agronomic and energetic potential of biomass sorghum genotypes. American Journal of Plant Sciences, v. 6, n. 1, p. 1862-1873, 2015. COELhO, A. M. et al. Seja o doutor do seu sorgo. Informações Agronômicas, v. 14, n. 100, p. 1-12, 2002.

EMPRESA BRASILEIRA DE PESQUISA AGROPECUÁRIA (Embrapa). Manual de análise química de solos, plantas e fertilizantes. 2. ed. Brasília, DF: Embrapa Informação Tecnológica, 2009.

EPSTEIN, E.; BLOOM, A. J. Nutrição mineral de plantas: princípios e perspectivas. 2. ed. Londrina: Ed. Planta, 2006.

FORZANI, C.; DUARTE, G. T.; MEYER, C. The plant target of rapamycin kinase: a connecTOR between sulfur and growth. Trends in Plant Science, v. 23, n. 6, p. 472475, 2018.

GUEDES, E. M. S. et al. Fosfato natural de Arad e calagem e o crescimento de Brachiaria brizantha em Latossolo Amarelo sob pastagem degradada na Amazônia. Revista de Ciências Agrárias, v. 52, n. 1, p. 117-129, 2011.

KOCHENOWER, R. et al. High plains production handbook. Lubbock: United Sorghum Checkoff Program, 2016.

MAY, A. et al. Plant population and row spacing on biomass sorghum yield performance. Ciência Rural, v. 46, n. 3, p. 434-439, 2016.

MAY, A.; SILVA, D. D. da; SANTOS, F. C. dos. Cultivo do sorgo biomassa para a cogeração de energia elétrica. Brasília, DF: Embrapa Milho e Sorgo, 2013.

NEXSTEPPE sorgo biomassa Palo Alto. Campinas: Departamento de Assistência Técnica Nexsteppe Brasil, 2015.

PANNACCI, E.; BARTOLINI, S. Evaluation of sorghum hybrids for biomass production in central Italy. Biomass and Bioenergy, v. 88, n. 1, p. 135-141, 2016.

RIBEIRO, A. C.; GUIMARÃES, P. T. G.; ALVAREZ, V. H. Recomendações para uso de corretivos e fertilizantes em Minas Gerais: $5^{\text {a }}$ aproximação. Viçosa: Comissão de Fertilidade do Solo do Estado de Minas Gerais, 1999.

SANTI, A. et al. Deficiências de micronutrientes em sorgo (Sorghum bicolor). Revista de Ciências Agroambientais, v. 3, n. 1, p. 54-63, 2005. 
SANTOS, F. C. et al. Adubação nitrogenada e potássica na nutrição e na extração de macronutrientes pelo sorgo biomassa. Revista Brasileira de Milho e Sorgo, v. 14, n. 1, p. 10-22, 2015.

SANTOS, F. C. et al. Adubações nitrogenada e potássica no sorgo biomassa: produtividade e qualidade de fibra. Revista Brasileira de Milho e Sorgo, v. 13, n. 1, p. 1-13, 2014.

SANTOS, H. C. et al. Cu e Zn na cultura do sorgo cultivado em três classes de solos: I. Crescimento vegetativo e produção. Revista Brasileira de Engenharia Agrícola e Ambiental, v. 13, n. 2, p. 125-130, 2009.

SERRA, P. et al. Coupling biomass sorghum and wheat straw to minimise the environmental impact of bioenergy production. Journal of Cleaner Production, v. 154, n. 1, p. 242-254, 2017.

SHAN, L. et al. Effects of long-term nitrogen and phosphorus addition on plant defence compounds in a freshwater wetland. Ecological Indicators, v. 94, n. 1, p. 1-6, 2018.

SILVA, J. M. F. D. et al. Row spacing, plant density, sowing and harvest times for sweet sorghum. Pesquisa Agropecuária Tropical, v. 47, n. 4, p. 408-415, 2017.

SOUSA, D. M. G.; LOBATO, E. Cerrado: correção do solo e adubação. 2. ed. Brasília, DF: Embrapa, 2004.

STRECKII, L. C. W. N. A.; ROSAIII, H. T. Desenvolvimento vegetativo e reprodutivo de cultivares de trigo e sua associação com a emissão de folhas. Ciência Rural, v. 39, n. 8, p. 2320-2326, 2009.

TAIZ, L. et al. Fisiologia vegetal. 6. ed. Porto Alegre: Artmed, 2017.

VENEGAS, J. G.; HARRIS, R. S.; SIMON, B. A. A comprehensive equation for the pulmonary pressurevolume curve. Journal of Applied Physiology, v. 84, n. 1, p. 389-395, 1998. 